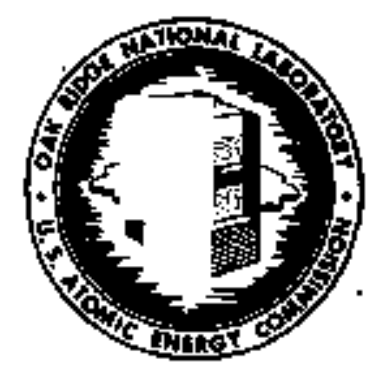

OAK RIDGE NATIONAL LABORATORY UNION CARBIDE NUCLEAR COMFANY

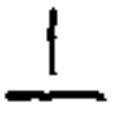

U[C

POST OFFICE $90 X \mathrm{P}$ OAK RIDGE, TENNESSEE

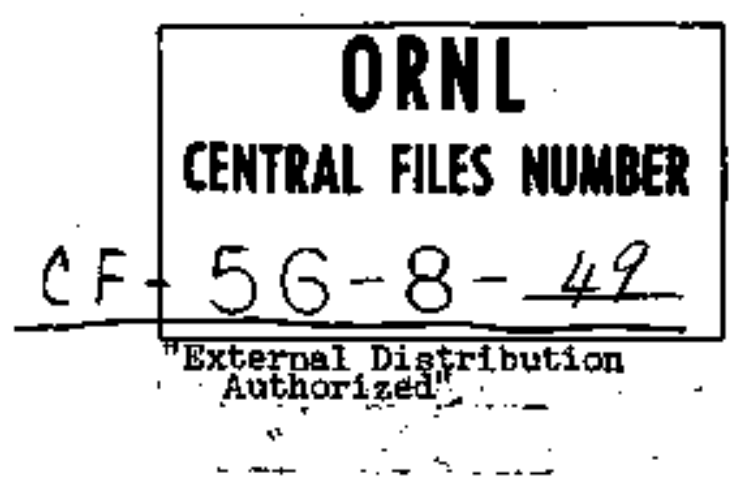

DATE: August 9, 1956

SUBJECT: Erfect of Xenon-135 Retention Upon Homogeneous Reactor Behiviar

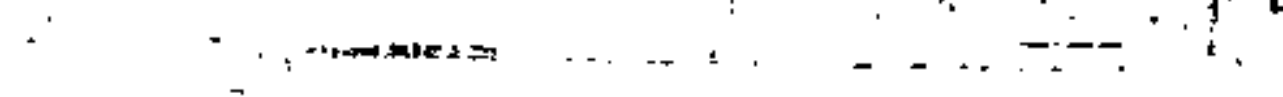

Photortat Prices Pholoslat Price $s$ Microfilm Pries 5 $-4$

Availoble from the

Office of Technical Services Deportment of Commeree Wahington 25, D. C.

\title{
LEOL NOTICE
}

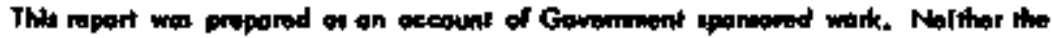

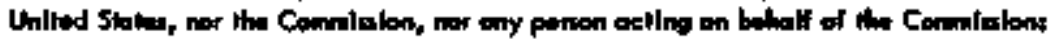

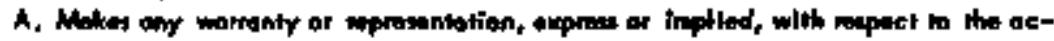

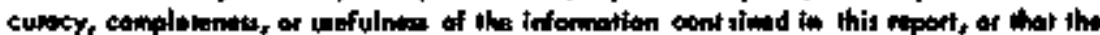

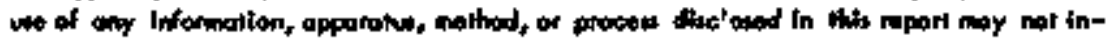
fotnop privably owned righks of

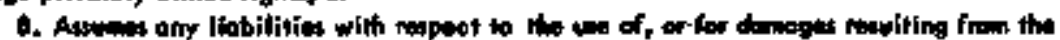

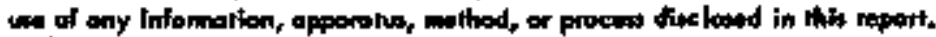

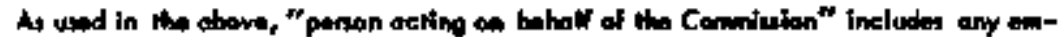

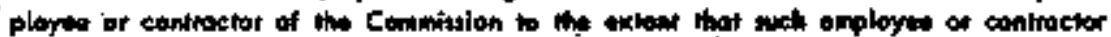

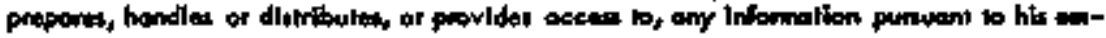

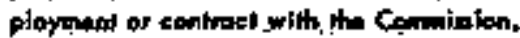
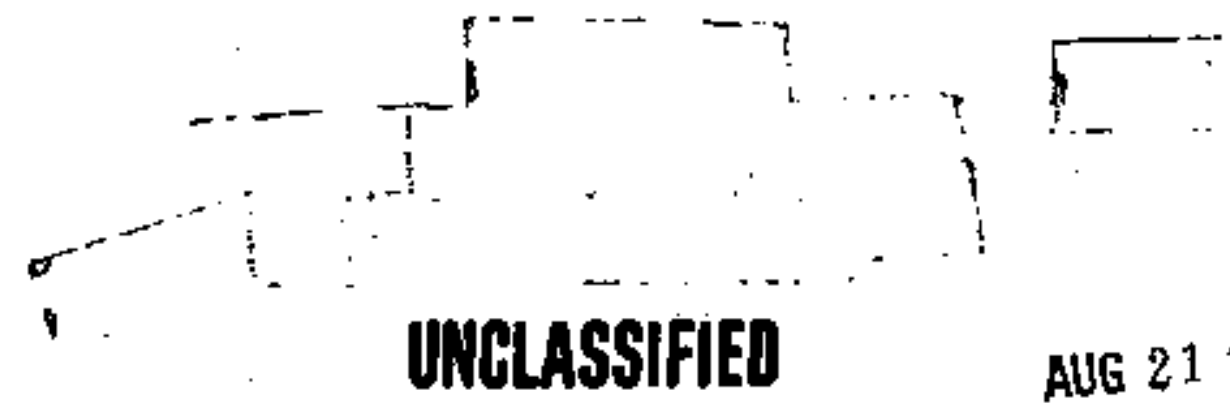

$$
\text { ; }
$$

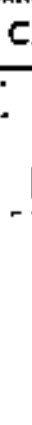




\section{DISCLAIMER}

This report was prepared as an account of work sponsored by an agency of the United States Government. Neither the United States Government nor any agency Thereot, nor any of their employees, makes any warranty, express or implied, or assumes any legal liability or responsibility for the accuracy, completeness, or usefulness of any information, apparatus, product, or process disclosed, or represents that its use would not infringe privately owned rights. Reference herein to any specific commercial product, process, or service by trade name, trademark, manufacturer, or otherwise does not necessarily constitute or imply its endorsement, recommendation, or favoring by the United States Government or any agency thereof. The views and opinions of authors expressed herein do not necessarlly state or reflect those of the United States Government or any agency thereof. 


\section{DISCLAIMER}

Portions of this document may be illegible in electronic image products. Images are produced from the best available original document. 


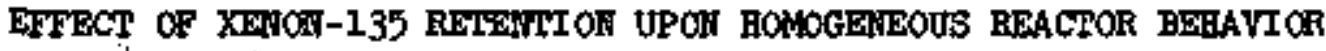

Abstract

If aqueous bonogeneous reactors are operated with complete recombination of the decomposition gases and no letdown of the high-presidure aystem, there . vill be complete retention of the fisalon fragment and product gased within the reactor eystem. Under such conditions, partial or total reactor shutdow would lead to an increace in Xe-135 concentration, which may lead to deflculties in anintining critfceltig during elther the ohutdown periad or upon returning the reactor to full power. To investigate the effects of xenon concentration transients, calculations were performed for the cage of a 4-ft diameter opherical reactor operating at $280^{\circ} \mathrm{C}$, containing $\mathrm{U}-235$, heavs uater, $I-135$, and $X e-135$, and at initial fluxes of $10^{13} \div 10^{15}$ neutrons/cm ${ }^{2}-$ eec. " The reantor power wat reduced to fractions of efither O or 0.1 of the inftiel value, and when the xeinon concentration had reached a maximum, the reactor power wes increased to ita origingl value. The reaulta obtained abow that rates of concentretion change, temperature rise, and reactivity addition which way be associated with the bufld-up or burn-out of xemon are low enough to allow gufficlent time for corrective messures. However, the total change in temperature or fuel concentration which might be required to matntein critfeality may be so large that reliance on either control alone would be impractical. For example, if the flux were 1nitially $10^{14}$, a $35 \%$ increase in fuel concentration would be needed to keep the resctor aritical at the orfginel temperature up to the peak xeinon concentration. So large an inventory of extra fuel ia clearly undeoirable from the itiandpotnte of both economieg and safety. stmilwrly, large temperature changes would

All fluxes mentioned in this report are average values beged on. the entire system volume and not on the cors slone. 
Jnclassifled

result if the concentration were kept conetant, A combination of temperature and concentration control, or renoval of xenon by continuous let-down of fuel solution or gas sparging vould appenr to be necessary; the exact approach to be used would have to be determined in conformance wt th individual condftion. In uging gas sparglng gote care woold be needed to evold sudien large resctivity additions, although it appears that fairly raptd zenon reuloval by this mean is generally posstble if th axfety. Is decompostion gages were allowed to form, the effect of xenon concentration changes would be reduced to negilgible levels. 


\section{ANATYSIS:}

The questroing to be examined are the following:

1. If a howogensoug reattor is thut-aown partially or totally how much dificulty in alntaining erfticality 1s presented by the sibgequant xenon buila-up?

2. If, after such a ghut-down, the resctor 1s wade to deliver: power at the origipal rate, does the raptd burn-out of zenon lead to large rates of reactivity addition?

3. What are the congequenceg of audden xenon removal by sparging or other means?

These questions were studied by examining a fes extreme conditiong, ag it 1s not possible to lnveatigate all pogatble rariationg which might be experienced.

1. Minteining criticelity ofter Furtiat or Total Shutdowa.

An extreme wituation exampned was the case of no xenon removel either before or after partiel ohutdpm. Bere, the reactor 1: operating at equilibrim at some hibh-power level, and the power level is suddenly reduced. The xenon concentration will increase to a maximin due to reduced buro-cut. How rapldily must the eritical concentration be altered to maintein criticallty at the same average. reactor tenperature? Consider a bare thertial reactor of buckling $\mathrm{B}^{2}$. Ageume that throughout the xenọn trapsient the resctor 1a just critical. (Monentary ourges due to the rediction in power will be damped out 
rapidiy and rill not have any partịcular effect upon the xenon level.) since (beglecting resonadce capture and changer in $\sim$ and $\mathrm{D}_{2}$ due to chagget in fuel copcentretion)

$$
1=\frac{\eta \Sigma_{a}(25)}{\left(1+T B^{2}\right)\left(\Sigma_{B}(25)+\Sigma+\Sigma(X e)+D_{2} B^{2}\right)}
$$

then at all times

$$
\frac{a \Sigma_{a}(25)}{a t}=\frac{\left(1+T^{2} e^{2}\right)}{\eta-\left(1+\tau^{-} t^{2}\right)} \frac{d \Sigma(x e)}{d t} \text {. }
$$

After a reduction in power, the largest value of $\frac{d x_{e}}{d t}$ will be leas than $\lambda(I) H(I)_{0}$ were the zero subseript refers to the concentration of lodine at the t1ue of power reduction. The fodine coneentration is

$$
[\mathrm{L}(\mathrm{I})]_{0}=\frac{\Sigma_{\mathrm{f}} \bar{\phi} \mathrm{y}(\mathrm{I})}{\lambda(I)}
$$

(where $\bar{\phi}$ is the average fliux over the entire ayatem volume) ao thet

$$
\frac{1}{\Sigma_{a}(25)} \frac{d \Sigma_{g}(25)}{d t}=\frac{1}{B(25)} \frac{a \underline{H}(25)}{a t}<\frac{\left(1+T B^{2}\right) \sigma(X e) \sigma_{f}(25) \bar{d} y_{I}}{\left[\eta-\left(1+T^{2} B^{2}\right)\right] \sigma_{a}(25)}
$$

The fractional rate of fuel concentration increase will be greater for larger fluxes an imaller reactors. However, épproximate number for $B^{2}$ and $\bar{\phi}$. ohow that this rate 1 s quite amall: 
Ùnclasgifled

6.

$$
\begin{aligned}
& T \mathrm{~B}^{2}-0.5 \text { (for a ophericel reactor around \& ft+D.) } \\
& y_{I}=0.056 \\
& \frac{\sigma(\mathrm{xe}) \sigma_{\mathrm{f}}(25)}{\sigma_{\mathrm{a}}(25)} \sim 3 \times 10^{-18} \mathrm{~cm}^{2} \\
& \bar{\phi}=10^{15} \text { neutrons } / \mathrm{cm}^{2}-\text { sec (extremely high) } \\
& \frac{1}{\mathrm{~B}_{25}} \frac{\mathrm{dr}}{\mathrm{dt}}<0.056 \frac{1.5}{0.5} \times 3 \times 10^{-18} \times 10^{15}=5 \times 10^{-4} \mathrm{Bec}^{-1}
\end{aligned}
$$

Thus, it is seen that for a small reactor at an extremely high flux, the maxinum rate of concentretion change to maintaln criticality is less then $0.05 \%$ per second. (Fote thet there 18 no dependence upon $\Sigma$ for a given initial flux as long as $\Sigma$ le constant.) A more realiatic example is represented by the curves in Fig. 1. There, a reactor $4 \mathrm{ft}$ in diameter containing only heavy water, $\mathrm{U}-235$, and xenon, operating at $200 \mathrm{Mw}$ 1s ghut aiown to $20 \mathrm{Mw}$. The total sygte volume was taken as 11000 Itterg, corresponding approxiately to a $20 \mathrm{kw}$ per lfter external systen power denglty and about $200 \mathrm{kw}$ per 1 tter in the core. The everage flux In the gyatem was about $7 \times 10^{13}$ at full power. A ats. 1 showg, the necessary rate of fuel increase is quite low, which indicates that reseondble opportuntty exists for taking corrective measires. However, it is clear that an undesireble large total fuel adaition would be required if concentration control were tued, and therefore temperature control or sparging, or both, woula be neceseary aleo.

\section{Fesctivity Additions arter Return to Oribinal Power.}

Returning to original power may be a far more eerious matter than maintaining oriticality aftar a partial obutdown. In this case, the 
problem is to prevent the reactor from becoming eupercritical due to the rapid burnout of the excess zenon. Suppoge that the xenon concentretion has riaen to the point where $\Sigma(\mathrm{Xe})=\frac{1}{2} \Sigma_{\mathrm{a}}(25)$. At high fluxes, the rate of change of xeaon concentration will be approxidately.

$$
\frac{d \mathrm{H}(\mathrm{Xe})}{\mathrm{dt}}=-\mathrm{H}(\mathrm{Xe}) \sigma_{\mathrm{xe}} \bar{\theta}=-\frac{1}{2} \Sigma_{\mathrm{a}}(25) \bar{\phi} \text { inftially for the }
$$

cases we have chosen. Then by equation (2) the lergest fractional concentration change rate is

$$
\frac{1}{\sum_{a}(25)} \frac{d \Sigma_{A}(25)}{d t} \sim \frac{1+\tau_{B}^{2}}{\eta-\left(1+\tau_{B}^{2}\right)} \quad \frac{\partial\left(X_{e}\right)}{2}
$$

Uafig the same numbers ag before we obtain a maximum fractionsl concentration change rete of $\sim \frac{1}{2} \$$ per eecond. A rate of this elze might indeed be difficult to manege. However, detalled study of more reaconable cases shows no ouch raplà rates. Calculations were performed. for which the origtand elux had values of $10^{13}, 10^{14}$, and $10^{15}$, for a l-ft diameter epherleal reactor at $280^{\circ} \mathrm{C}$ contalaling $\mathrm{J}-235, \mathrm{D}_{2} \mathrm{O}$, and Xenon. The porter was reduced to fractions of 0 and 0.1 of the initial value in each ease. The xenon was permitted to reach a maximum, at which point the power was returned to the original value. The following information was obtained at the return-to-power point:

In (Xe), the waximum xenon conentration $\mathrm{A}_{\mathrm{m}}(25)$, the uaxtmum fuel concentration $\frac{d k_{0 f f}}{d t}$, the rate of chenge of the maltiplication congtant
if the fuel concentretion vere left unchanged. 


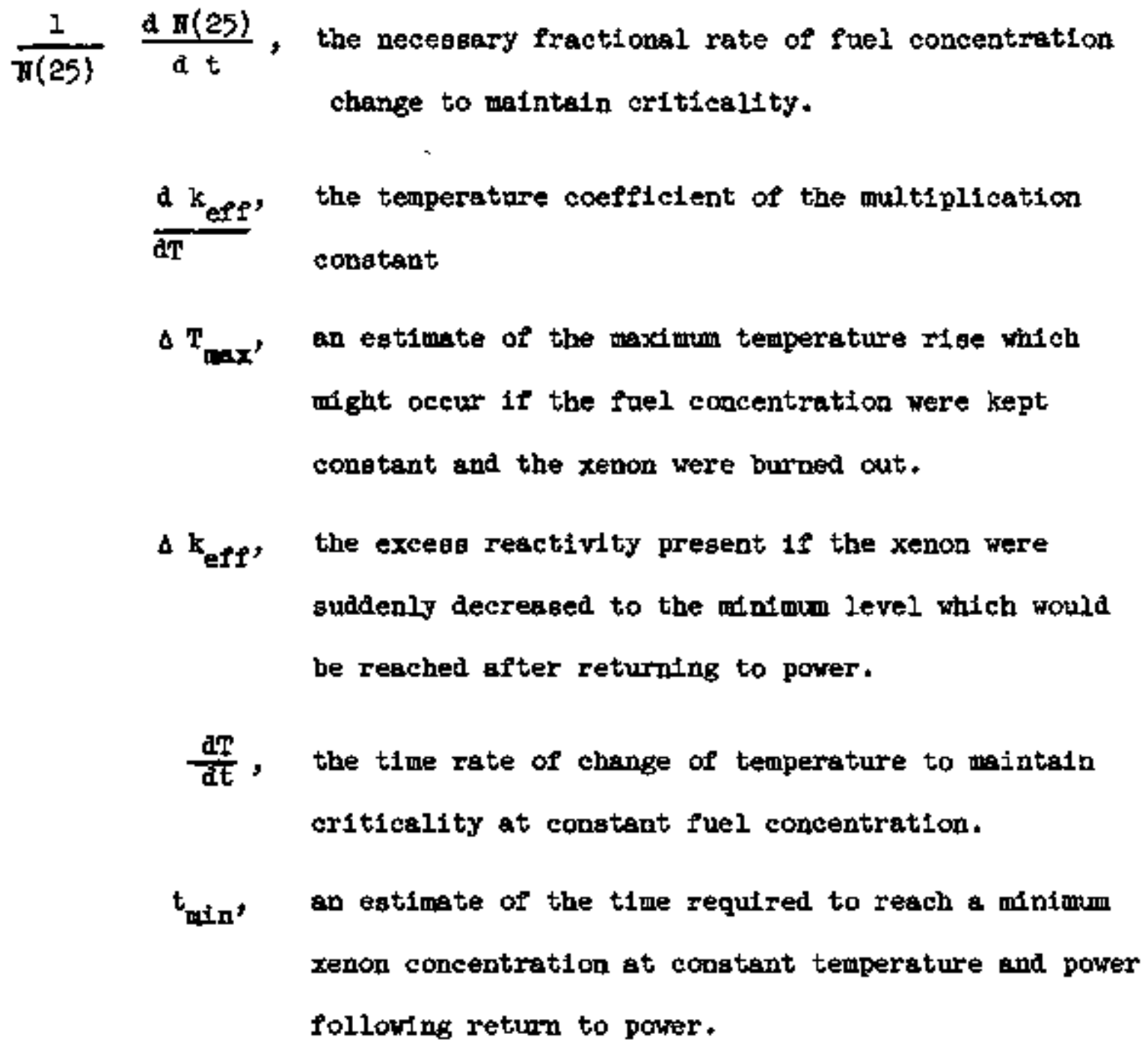

The following anelyaia wa perforated to determine the deaired quant1ties:

To determine xenon concentratione, the differential equatione

$$
\begin{aligned}
& \frac{d \mathrm{~d}(I)}{d t}=\mathrm{y}(\mathrm{I}) \frac{\mathrm{KP}}{\mathrm{V}_{\mathrm{s}}}=\lambda(\mathrm{I}) \mathrm{n}(\mathrm{I}) \\
& \frac{d w\left(X_{e}\right)}{d t}=\lambda(I) n(I)+y\left(x_{e}\right) \frac{\mathrm{KP}}{\vec{V}_{g}}-\left(\lambda\left(X_{e}\right)+\sigma\left(X_{e}\right) \bar{\phi}\right) H\left(X_{e}\right)
\end{aligned}
$$


were solved subject to the boundary conditions

$$
N(I)_{0}=\frac{y(I) K P(0)}{V_{6} / I}
$$

and $H(X e)_{0}=\frac{y(I)+y(X e)}{\lambda(X e)+\sigma(X e) \bar{Q}(0)} \frac{K P(0)}{V_{\theta}}$

where the eubecript 0 Indicates en intitel concentration. Where a purely anslytical solution was enployed, constant power and conetant flux were assumed. If $\sigma(\mathrm{Xe}) \bar{\phi}$ is leag than $\lambda(\mathrm{Xe})$, the constant flux asoumption is quite accurate. In those ceses where $\sigma\left(X_{t}\right) \phi$ was greater then $\lambda(\mathrm{Xe})$, the solution wa broken up into tine intervals of one hour during which the rlux was taken congtant at the value at the start of thet interval. Since such a procedure is rather lengthy, : and bigh accuracy wo not essential for the purposes of thit report, f1alte Interval calculationa were peed on ly were necessary to avoid a Large error.

The solutions to (5) and (6) eesuming constant flux are

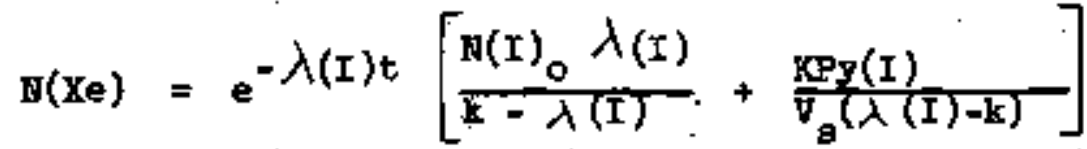

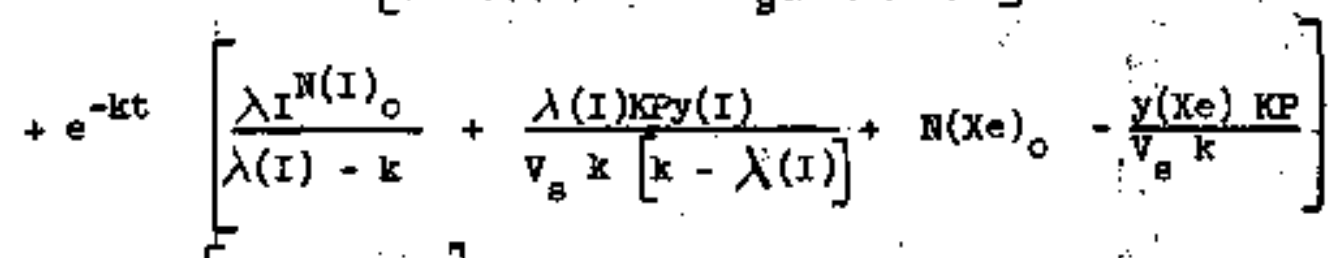

$$
\begin{aligned}
& +\frac{\operatorname{sP}\left[\mathrm{L}(\mathrm{I})+\mathrm{y}\left(\mathrm{X}_{\theta}\right)\right]}{\mathrm{v}_{\mathrm{s}} \mathrm{k}}
\end{aligned}
$$

where $\mathrm{z}=\lambda\left(\mathrm{Xe}_{\mathrm{e}}\right)+\sigma\left(\mathrm{Xe}_{\mathrm{e}}\right) \bar{\phi}$

$\mathrm{H}(\mathrm{I})=\left[\mathrm{H}(\mathrm{I})_{0} \cdot-\frac{\mathrm{KP} \mathrm{y}(\mathrm{I})}{\mathrm{v}_{\mathrm{i}} \lambda(\mathrm{I})}\right] \mathrm{e}^{-\lambda(\mathrm{I}) \mathrm{t}}+\frac{\mathrm{KP} \mathrm{y}(\mathrm{I})}{\mathrm{V}_{\mathrm{a}} \lambda(\mathrm{I})}$ 
Hote that the lodine concentration expression is correct for constant pover and is Independent of Plux varlations, The waximutin xenon concentration va foud elther by differentioting (9) and equating the derivative to zero, of aumerically where the finte difference method wos used.

The concentration of fuel required was found from the two-group critical equation for a bare reactor:

$$
H(25)=\frac{\left(1+\tau B^{2}\right)\left(\Sigma+\Sigma\left(X_{e}\right)+D_{2} B^{2}\right)}{\sigma_{B}(25)\left(\eta-\left(1+T B^{2}\right)\right)}
$$

The necessary rate of change of ruel concentration to achleve criticallty is

$$
\frac{d H(25)}{d t}=\frac{\sigma\left(X_{e}\right)\left(1+\tau_{B}^{2}\right) \frac{d\left(X_{e}\right)}{d t}}{\sigma_{a}(25)\left[\left(\eta-\left(1+T_{B}^{2}\right)\right]\right.} .
$$

The derivetive, $d x(X e) / a t$, is obtained by differentiating equation (9), and the frectional rate of change of concentration is calculated by dividing (12) by $\mathrm{r}(25)$.

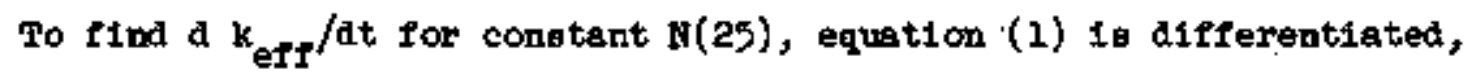
noting that the reactor is juat critical at the point were the ạerivstive 18 taken:

$$
\begin{aligned}
& \frac{d k_{e f f}}{d t}=-\frac{\eta \Sigma_{a}(2 S) \frac{d \Sigma\left(X_{e}\right)}{d t}}{\left(1+T_{B}^{2}\right)\left(\Sigma_{a}(25)+\Sigma+\Sigma\left(X_{e}\right)+D_{2^{B}}{ }^{2}\right)^{2}} \\
& =-\frac{1}{\Sigma_{\mathrm{a}}(25)+\Sigma+\Sigma(\mathrm{Xe})+\mathrm{D}_{2} \mathrm{~B}^{2}} \frac{\mathrm{d} \Sigma(\mathrm{Xe})}{\mathrm{dt}}
\end{aligned}
$$$$
\frac{d x_{e f f}}{d t}=-\frac{\left(1+T B^{2}\right) d(X e)}{\eta \Sigma_{a}(25)} \frac{d x(X e)}{d t}
$$ 
The tenperature coefficient at the patnt of maximum xenon concentration was deterwived by calculating $\mathrm{k}_{\text {eff }}$ et $285^{\circ} \mathrm{C}$ under the aseumption that the ratio of fuel and xeson concentrations to water concentration was constant, 80 that

$$
\frac{d k_{e f f}}{d !}=\frac{k_{e f f}\left(285^{\circ}\right)-1}{5} o_{c}^{-1}
$$

The tempersture riae which might oceur, if the reactor vere allowed to burn out the xenon wi thout changing wrantum concentration was also estlmated. After returning the reactor to full power the xenon concentration will decline to a minimum value and then increase asymptotically to the origingl equilibrium value. This thindmin xenon concentration was egtimated by differentiation of equation (9), and the increse in keff using this xenon concentration and the maximum fuel concentration was computed. (For blgh fluxea, the zenon concentretion so calculeted is too high; in such cases the xenon was neglected with littie error because even the overestimated palue 1a atill too amall to aeriously affect $\Delta \mathrm{k}_{\text {eff. }}$ ) Dividing $\Delta \mathrm{k}_{\text {eff }}$ by the temperature coefficient of: reactivity obtalned by equation (14) gave a rough estinate of the aize of the tenperature rise vhtch alght be experienced.

To obtain the maxpmu rate of temperatore incresge, i $\mathrm{k}_{\mathrm{efr}} / \mathrm{dt}$ WB atvided by the temperature coefficient:

$$
\frac{\mathrm{dT}}{\mathrm{dt}}=-\frac{\mathrm{dk} \mathrm{eff}^{/ d t}}{\mathrm{dk} \mathrm{eff}^{/ d x}}
$$

Table I aumarizea the results which have been obtained. Fote that for a given resctor size, the maximum xeoon concentration achieved after. ahutdow is larger for larger inttial fluxes. toually, the value 
Effects of Xenon Concentration Var1ation on Resctor Characterf gtice Following Return to Power from a Partial or Total Shutdorm. Xenon Concentration

at Maximum Upon Return to Poter

\begin{tabular}{|c|c|c|c|c|c|c|c|c|c|c|c|}
\hline $\begin{array}{l}\text { Reactor } \\
\text { Diameter } \\
\text { Pt. }\end{array}$ & $\phi_{0}$ & $\frac{P}{P_{0}}$ & 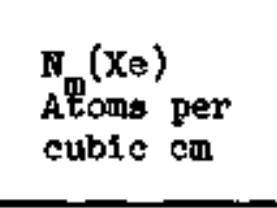 & $\begin{array}{l}\mathrm{H}_{\mathrm{m}}(25) \\
\text { Atons per } \\
\text { barc-cil }\end{array}$ & $\frac{\mathrm{ak}_{\mathrm{eff}}}{\mathrm{dt}}$ & $\underset{\substack{\mathrm{N} \\
\mathrm{N}(25)}}{-1} \frac{\mathrm{dr}(25)}{\mathrm{at}}$ & $\frac{-d k_{\text {effe }}}{{ }^{{ }^{\circ} \mathrm{c}^{-1}}}$ & $\begin{array}{l}\Delta T_{\max } \\
\mathrm{o} \mathrm{C} . \\
\text { (Approx. }\end{array}$ & $\begin{array}{l}\Delta \mathrm{k}_{\text {efr }} \\
{ }^{\circ} \mathrm{C} .\end{array}$ & $\begin{array}{c}\frac{\mathrm{dT}}{\mathrm{dt}} \\
\mathrm{o}_{\mathrm{c}}^{\mathrm{c} / \mathrm{sec}} \\
\end{array}$ & 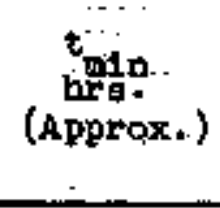 \\
\hline 4 & $10^{13}$ & 0.1 & $1.34 \times 10^{14}$ & $2.72 \times 10^{-5}$ & $6.48 \times 10^{-7}$ & $2.66 \times 10^{-6}$ & $3.69 \times 10^{-3}$ & 2 & $7.5 \times 10^{-3}$ & $1.75 \times 10^{-4}$ & 10 \\
\hline 4 & $10^{13}$ & 0 & $1.38 \times 10^{14}$ & $2.73 \times 10^{-5}$ & $7.3^{6} \times 10^{-7}$ & $3.03 \times 10^{-6}$ & $3.69 \times 10^{-3}$ & 2 & $8.6 \times 10^{-3}$ & $2.00 \times 10^{-4}$ & 10 \\
\hline 4 & $10^{14}$ & 0.1 & $6.15 \times 10^{14}$ & $3.77 \times 10^{-5}$ & $1.66 \times 10^{-5}$ & $6.84 \times 10^{-5}$ & $3.36 \times 10^{-3}$ & 20 & $6.6 \times 10^{-2}$ & $4.95 \times 10^{-3}$ & 5 \\
\hline 4 & $10^{14}$ & 0 & $9.28 \times 10^{14}$ & $4.46 \times 10^{-5}$ & $2.08 \times 10^{-5}$ & $8.54 \times 10^{-5}$ & $3.22 \times 10^{-3}$ & 30 & $1.0 \times 10^{-1}$ & $6.46 \times 10^{-3}$ & 5 \\
\hline 4 & $10^{15}$ & 0.1 & $1.46 \times 10^{15}$ & $5.63 \times 10^{-5}$ & $1.68 \times 10^{-4}$ & $6.87 \times 10^{-4}$ & $3.07 \times 10^{-3}$ & 40 & $1.2 \times 10^{-1}$ & $5.46 \times 10^{-2}$ & I \\
\hline 4 & $10^{15}$ & 0 & $8.63 \times 10^{15}$ & $2.14 \times 10^{-4}$ & $8.61 \times 10^{-5}$ & $3.53 \times 10^{-4}$ & $2.64 \times 10^{-3}$ & 50 & $2.7 \times 10^{-12}$ & $3.27 \times 10^{-2}$ & 3 \\
\hline$\infty$ & $10^{15}$ & 0 & $3.06 \times 10^{13}$ & $2.98 \times 10^{-7}$ & $3.57 \times 10^{-4}$ & $6.88 \times 10^{-4}$ & $1.08 \times 10^{-3}$ & $>50$ & $5.1 \times 10^{-1}$ & $3.32 \times 10^{-2}$ & 2 \\
\hline
\end{tabular}




\section{4}

of $\mathrm{dk} \mathrm{eff} /$ at when power 18 restored will slso fncreses with incressing flux. However, since it is the intitial poser which was restored and not the Initial flux, the flux at the polnt of restoration of power mey be depreseed enough to show a smaller value of $\mathrm{dk}_{\text {eff }} / \mathrm{dt}$. Indication of this 10 grven in the $10^{15}$ flwx caee for a 4-ft reactor, where the reduction to 0.1 of the ortginel jower shows a higher $\mathrm{dr}$ eff $/ \mathrm{at}$ than. for reduction to zero power.

For a given flux, larger reactor will have a emaller maxdmun concentration of xenon after shutiom than sxaller reactors, since this concentration depends upon the original power denglty (1.e., the original equilibrium lodine concentration). Since, for bigh fluxes, at the retian to power point:

$$
\frac{d \pi\left(X_{e}\right)}{d t} \sim-\Sigma\left(X_{e}\right) \bar{\phi}
$$

It follows fron equation (13) thet

$$
\frac{d k_{\text {eff }}}{d t}=+\frac{\left(1+\tau_{B}^{2}\right) \sigma(X e)}{\eta \Sigma_{d}(25)} \Sigma(X e) \emptyset
$$

If we wake the further approxtmation that $\Sigma\left(X_{e}\right)$ is proportionsl to the or1ginal power; 1.e., to $\left[\Sigma_{a}(25)\right]$ o $\phi_{0}$ then we have

$$
\frac{d k_{e t 1}}{d t} \sim \frac{\left(1+\tau_{B}^{2}\right)\left[\Sigma_{a}(25)\right]_{0}^{2} \phi_{0}^{2}}{\left[\Sigma_{8}(25)\right]^{2}}
$$

For a given $\phi_{o}$, it would appesr that $\mathrm{dk}$ eff $/ \mathrm{d} t$ is proportionsl to the square of the ratio of the initial and Itmal fuel concentrations. Geaerally opeaking, the ampller the reactor, the emslier this ratio will 
be, ao' that dx eff/at Increages with Increaging gize. Formula (18) also suggests thet for a given $B^{2}$ and $\phi_{\phi}$, $\frac{d k \text { eff }}{d t}$ uhould not be atrongly temperature dependent except where the fast leakage la high. Combination of equationg (12) and (13) leads to the following proportfonality between the time rate of change of multiplleation constant and fractional concentration change rete necegeary to maintaln criticality:

$$
\frac{1}{\bar{H}_{25}} \frac{d F_{25}}{d t}=-\frac{d k_{\text {eff }}}{d t}\left[\frac{\eta}{\eta-\left(1+T_{B}{ }^{2}\right)}\right]_{1}
$$

For large reactors (low fagt leakage) the required concentration change rate would increase in absolute value with atze at a given flux. For Fery small reactor, however, the situation might be reversed aince

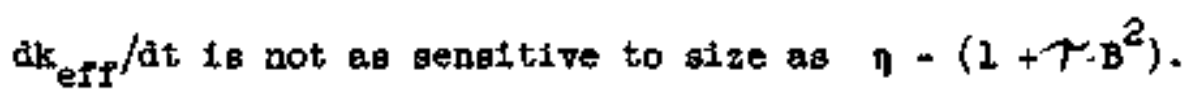

Although the eatimates of $\Delta T_{\max }$, the temperature to which the reactor whot rise if left at the maxdmum concentration, are large at the higher Ploxes, the rates at which reactivity or temperature might rige are rather blow even for the most extreme cases. It nuat also be remembered that these resulta refer to reactor systeng in which xenon is removed only by neptron absorption and decay. Here a reasonable rode of continuous xenon removal by gtripping included in the calculation all the effects would be practically eliminated.

3. Reactivity Effecte Produced by Sudden Xenon Removal.

To cslculations were made concerning this type of operation, but eome observations nay be made based on what has been done. Suppose a reector were partially shut dow and no means of gradually increasing the concentration were employed. The resctor would becone suberiticel due to xenon buildup, and the temperature vould fall. If the reactor 
Unclageified

$$
16
$$

temperature fell $10^{\circ} \mathrm{C}$, rapid reduction of the-xenon concentration to 1 ta orfginal level by sparging, or other meana, would be equitalent to introducing a $\Delta k_{\text {eff }}$ of about 0.03 .over a short-time 1nterval. Thus, only gradual removal of the xenon should be permitted in order to restore the reactor to criticality. Equation (13) may be used to compute the fractional rate of xenon removal correaponding to a certain rate os change of $k_{\text {eff }}$ near criticality: $\frac{1}{N(X e)} \frac{d a\left(X_{e}\right)}{d t}=-\frac{\eta \Sigma_{a}(25)}{\left(1+\tau^{2}\right) \Sigma\left(X_{e}\right)} \frac{d k_{e f f}}{d t}$

If dkef/dt is not to exceed $0.005 \mathrm{eec}^{-1}$, then at typical values of $1+\tau_{B}{ }^{2}=1.5$ and $\Sigma\left(X_{e}\right) / \Sigma_{a}(25)$ of 0.2 , the xenon concentration would bave to be reduced at a rate less than about $3.3 \%$ per ascond. A fairly rapid removal rate euch as this ouggeats that it should usualiy be safe to renove xenon intermittently wi thout gevere reatrictione. Each case would have to be judged individusily, however.

Unclessiffed 
The Erowth and decay of xenon concentration reaulting from power level changet appears to of fer no serious problems in resctor operation even if no continuous xemon removal is enployed. Changes in reactivity and temperature appear to occur at sufficlently low retes so that the reactor may be kept under control by concentration or temperature adjustments or by interuttent stripping. While no one of theae methods may be suitable if used alone, it should be popelble to tind a simple and adequate combination of epproeches.

The equations and regulta suggest that the effects of xenon upon reactivity have only uderate dependence upos ef ther temperature or the amount of absorbers other than fuel or senon. As the reactor olze increases (1.e., the buckllog decreases) the effecti for a given 1nitial flux appear to decrease when power 1s lowered and to increase when the inltial power is restored.

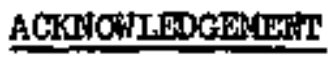

Thanks are due to Mrs. N. P. Lletzke who perforwed most of the neceesery computetions. 
TABLF II

Nuclear Coristants

1. Propertieg of $\mathrm{U}-235$

$$
\begin{aligned}
\eta(25) & =2.08 \\
\sigma_{f}(25) & =358 \text { barns }\left(280^{\circ}\right) \\
\sigma_{8}(25) & =424 \text { barns }\left(280^{\circ}\right) ; 419 \text { barde }\left(285^{\circ}\right)
\end{aligned}
$$

2. Properties of Xenon

$$
\begin{aligned}
& \sigma_{a}=3 \times 10^{6} \text { barno (absumed temperature independeat) } \\
& \lambda\left(\mathrm{Xe}_{\mathrm{e}}\right)=2.09 \times 10^{-5} \mathrm{aeca}^{-1} \\
& \mathrm{~g}\left(\mathrm{Xe}_{\mathrm{e}}\right)=0.003
\end{aligned}
$$

3. Propertieg of Iodine

$$
\begin{aligned}
& \lambda(I)=2.87 \times 10^{-5} \text { seco. } \\
& y(I)=0.056 . .
\end{aligned}
$$

4. Slow Diffusion Conetant, Age, and Absorption Crose Section of Heavy Water

$\begin{array}{cccc} & \mathrm{D}_{2}, \mathrm{~cm} & \tau, \mathrm{cm}^{2} & \Sigma_{\mathrm{a}}\left(\mathrm{D}_{2} \mathrm{O}\right), \mathrm{cm}^{-1} \\ 280^{\circ} \mathrm{C} & 1.23 & 216 & 4.44 \times 10^{-5} \\ 285^{\circ} \mathrm{C} & 1.25 & 222 & 4.37 \times 10^{-5}\end{array}$


$\mathrm{B}^{2}$, buckling, $\mathrm{cm}^{-2}$

$\mathrm{D}_{2}$, vlow diffugion conetant, cal.

k,$\lambda\left(x_{e}\right)+\sigma(x e) \bar{\emptyset}$

$x_{\text {eff }}$ effective multiplication conetant

$\Delta k_{\text {eff }}$ excesi multiplication constant

K, fisslons per megawatt-aecond

$\mathrm{N}(\mathrm{I}), \mathrm{N}\left(\mathrm{X}_{\theta}\right)$, concentration or Iodine and zenon, etome $/ \mathrm{cm}^{3}$

$\mathrm{N}(25)$, concentration of $\mathrm{J}-235$, atoms per bern-centimeter

$\mathrm{N}_{\mathrm{m}}(\mathrm{Xe}), \mathrm{H}_{\mathrm{m}}(25)$, waxlmum concentrations of xenon and $\mathrm{U}-235$, stome per con ${ }^{3}$

and atoms per barn-cm, respectively.

$\mathrm{H}(\mathrm{I})_{0}, \mathrm{H}(\mathrm{Xe}),{ }_{0}$ Inttial iodine and xenon concentrations, atowe per $\mathrm{cm}^{3}$

P , power, megawatis

$\mathrm{P}(\mathrm{O})$, initial power, megawatts

t , t1me, eeconds

tufn, time required to reach ainimul xenon concentration following

a return to orlgial power, boura

$\mathrm{T}$, temperatixe, ${ }^{\circ} \mathrm{C}$.

$\Delta \mathrm{r}_{\max }$, maximum temperature rise, ${ }^{\circ} \mathrm{C}$.

$\mathbf{v}_{\mathbf{g}}$, total aystern volume, cubic centimeters

$y\left(X_{e}\right), y(I)$, fission $y$ leld of xenon and lodine atoms, atous per tlesion

$\varepsilon_{\mathrm{B}}(25)$, macroscopic absorption croes nection in $\mathrm{tJ}-235, \mathrm{cal}^{-1}$

$\Sigma$, macroscopic cross section of reactor nuterial other than

fuel or xerion, $\mathrm{cm}^{-1}$

$\Sigma(X e)$, macroscopte croag aection of xenon, can ${ }^{-1}$

$\Sigma_{f}$, maçroncople flesion cross aection, $\mathrm{cm}^{-1}$ 
$\sigma\left(\mathrm{Xe}_{e}\right)$, atcroseople absorption cross section of zenon, $\mathrm{cm}^{2}$

$a x_{1}$

2

:.

10

$\lambda(\mathrm{xe}), \lambda(I)$

\section{$\overrightarrow{0}$}

, average neutron flux over neutrons $/ \mathrm{cm}^{2} / \mathrm{aec}$.

$T$ $\mathrm{U}-235$, barns

$$
\text { neutrons/cw /aes. }
$$

- Fermi Age, $\mathrm{cm}^{2}$ $\sigma_{1}(25), \sigma_{\mathrm{B}}(25)$, wieroscopic Iission and absorption cross sections of

- fisaton neutrone per absorption in fuel

- decay constanti of xenon and lodine, $\operatorname{secs}^{-1}$ 


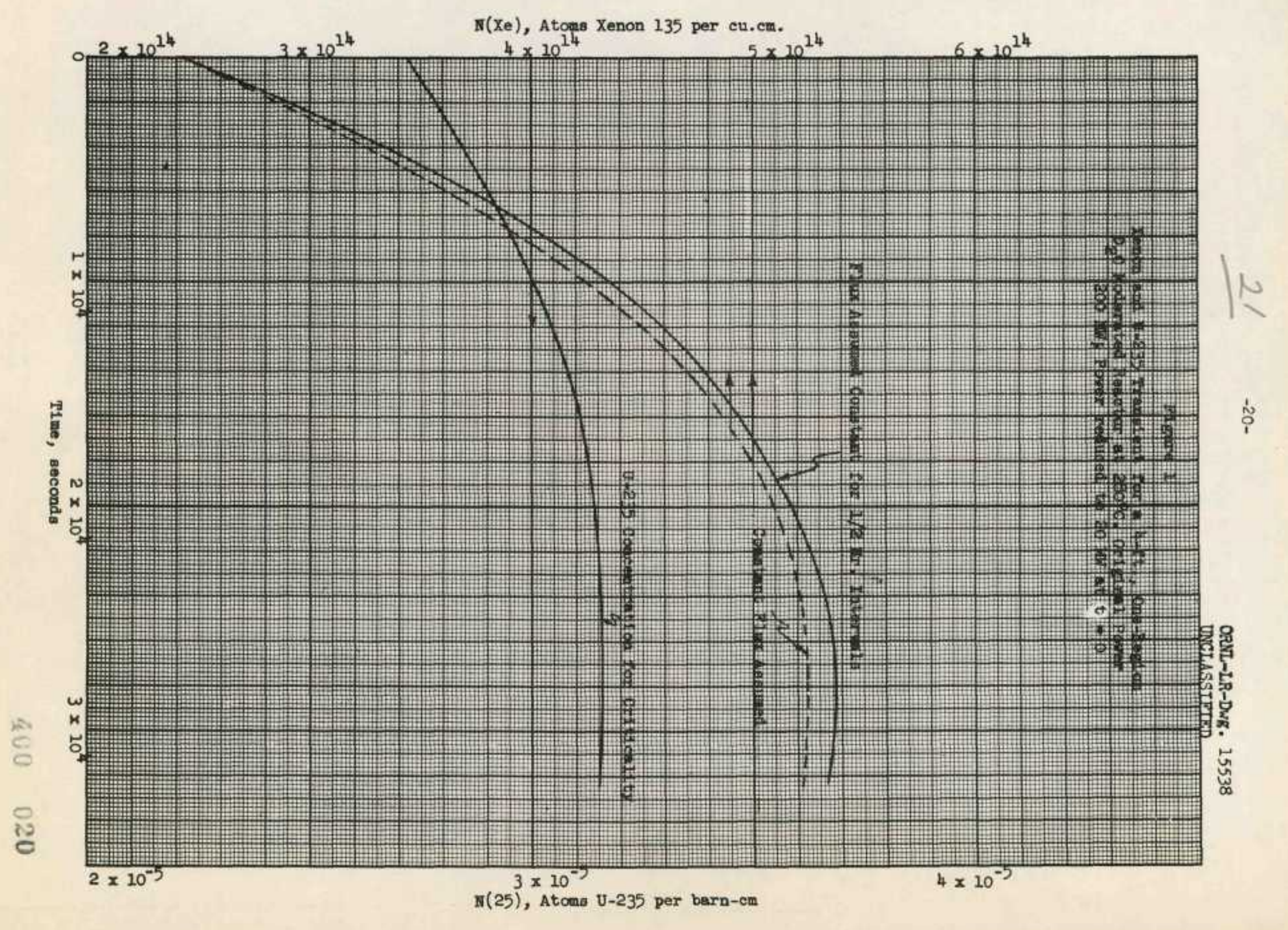




$$
|-2|
$$

